\title{
The Effectiveness of The Smart Indonesia Program in Sosa District
}

Emil Liza*, Suarman, Gusnardi

Economic Education Studies Program FKIP, Riau University, Pekanbaru, 28293, Riau, Indonesia.

\section{ARTICLE INFO}

Article history:

Received: 10 Jan 2021

Revised: 29 Juny 2021

Accepted: 03 July 2021

Published online: 24 July 2021

Keywords:

Effectiveness

Smart Indonesia Program

\begin{abstract}
A B S T R A C T
This study aims to determine the effectiveness of the implementation of the Smart Indonesia Program in Sosa District. This study used an evaluation research model, namely the Evaluation Countenance Stake model with a quantitative approach. The population in this study were all 153 students who received the Smart Indonesia Program for Senior High Schools in Sosa District, and the sample was taken using Isaac Michael's table totaling 105 people with an error rate of $5 \%$. The data were obtained using questionnaires and interviews, then analyzed descriptively by statistical means. The results of this study indicate that in general the implementation of the Smart Indonesia Program in Sosa sub-district has been carried out well. Furthermore, when viewed from several aspects related to the implementation of this program, the antecedent aspect is in the very good category, the Transaction aspect is in the good category, and the output aspect is in the good category. Thus, it can be stated that the implementation of the Smart Indonesia Program in Sosa sub-district has been carried out effectively, however, to be even more effective in implementing this program, it is hoped that the program implementers involved will be more selective in the process of submitting prospective recipients of the Smart Indonesia program, providing socialization to students and parents regarding the distribution of the Indonesia Pinta Program, and forming a monitoring team on the use of funds for the Smart Indonesia Program.
\end{abstract}

\section{Introduction}

Education is a right for every individual, as stated in the 1945 Constitution article 31 paragraph 1 which states that every citizen has the right to education, article 2 every citizen is obliged to attend basic education and the order is obliged to finance it. The free education program for the success of compulsory education 
launched by the government has not been implemented optimally. The problem of financing education has always been a crucial problem for the community, especially in the lower middle class (Aziz, 2019). Rahmanto in Kamsihayati, et al (2016) states that the educational problem faced by the government is the high number of children who do not continue their education at a higher level of education. Meanwhile, the government has declared 9 years of compulsory education and now it is 12 years of compulsory education. In supporting the realization of the 12-year compulsory education program, the government has prepared various programs, one of which is the Smart Indonesia Program.

According to the Regulation of the Minister of Education and Culture Number 9 of 2018, the Smart Indonesia Program, hereinafter abbreviated as PIP, is assistance in the form of cash from the government given to students who come from poor or vulnerable families in financing education. The Smart Indonesia Program (PIP) is one of the priority programs of the Ministry of Education and Culture (Kemendikbud) which aims to achieve equal distribution of education and a form of siding with children from poor and vulnerable families, this was stated by the Head of the Education Office of Nagan Raya Regency, Aceh Province. , Harbiah. PIP, he said, had a big impact on the community. The positive impact is not only for students and parents, but also for local governments in realizing equal distribution of education (liputan6.com). President Joko Widodo declared "Effective PIP Cuts Dropout Rates" at the National Education and Culture Meeting (jpnn.com, 2019). Furthermore, the Minister of Education and Culture Nadiem Makarim stated that education financing is one of the priority education programs in 2021. In 2021 the Ministry of Education and Culture has budgeted IDR 27.26 Trillion for education financing through the Smart Indonesia Program/Indonesian Smart School Card, Teacher Profession Allowances, KIP Lectures and Overseas Indonesian school development (Kompas.com). However, the reality is that the free education program for the success of compulsory education launched by the government has not been implemented optimally.

The role of the Smart Indonesia Program policy in several previous studies on the implementation of the Smart Indonesia Program, including the research of Aziz (2019) stating that the implementation of the Smart Indonesia Program has succeeded in improving the quality of education for the poor. Meanwhile, according to N.Rohaeni and Oyon Saryono (2018) the Smart Indonesia Program has also succeeded in creating equal distribution of education. Furthermore, Karmila, Zulfan, and Firdaus' research (2019) stated that the PIP policy is an educational policy that addresses students from dropping out of school to requiring students to complete education up to the high school stage or 12 years of compulsory education in a study entitled Effectiveness of the Smart Indonesia Program. of the 12-year compulsory education pilot. Astuti (2016) states that the Smart Indonesia Program has a very important role for the world of education, as educational accessibility helps equitable access to education so that students from underprivileged families can access education.

The word effective comes from English, namely effective which means successful or something is done successfully. Popular scientific dictionaries define 
effectiveness as the appropriateness of using the results or supporting the goals. According to Poerwadarminta in Arief (2018), effectiveness means that there is an effect (consequently, the impression), it is effective, efficacious, effective, so that its effectiveness can be understood as a result of something that is practiced or studied to get a maximum and satisfactory result or goal. According to Steers in Saraswati (2017) effectiveness which comes from the word effective, namely a job is said to be effective if it can produce one unit of output (output). Effectiveness according to Badrudin (2013) is the ability to do something right. Harbani Articleong (2012) states that effectiveness is the achievement of goals from a joint effort, the degree of target achievement indicates the degree of effectiveness, it can be concluded that effectiveness is the achievement of goals Mutiarin (2014) defines the effectiveness of circumstances that indicate the level of success or failure of management activities in achieving predetermined goals first. Sedarmayanti in Raman Marpin Pagau, et al (2018) suggests that effectiveness for an organization or institution can be seen from several criteria, namely input, production process, output and productivity. So effectiveness is a benchmark in achieving predetermined goals or objectives by an organization that can be seen from several criteria, namely input, process, and output. The effectiveness of the program referred to in this study is how big the ability of an education subsidy policy from the government, namely the Smart Indonesia Program (PIP) to achieve its goals.

Program evaluation is basically an evaluation activity of the implementation of a policy. To measure the quality of an educational program, an evaluation is needed (Suarman, et al., 2011). According to Fitzpatrick, Sanders \& Worthen in Darodjat and Wahyu (2015) evaluation is the identification, clarification and application of criteria to determine the value of an evaluation object (value/benefit) related to these criteria. According to Rusydi and Afida (2017) program evaluation is a unit or unit of activity that aims to collect information about the realization or implementation of a policy, takes place in a continuous process, and occurs in an organization that involves a group of people for decision making. So it can be concluded that program evaluation is a systematic activity comparing what has been achieved by a program with predetermined standards to find out how much success the planned program has.

According to Ara Hidayat and Imam Machali (2016) that financing education is a shared responsibility between the government, local governments and the community. It is the responsibility of the government and local governments to provide education budgets based on the principles of equity, adequacy and sustainability. According to Manoto Togatorop (2017) the cost of education is a resource issued by the government, the community, and parents of students to schools both in the form of goods and money that is collected and determined to achieve educational goals. Badrut Tamam (2018) defines education financing as an effort to raise funds to finance the operations and development of the education sector. From some of these opinions, the cost of education is an input component in the form of spending money either by individual students, families who send their children to school, individual community members, community groups or 
those issued by the government to finance school operations and the development of the education sector.

Sosa sub-district is located in the Padang Lawas district, which is part of the North Sumatra Province, which also implements the Smart Indonesia Program (PIP). The Indoesia Pintar Program is a refinement program of the Poor Student Assistance Program which is implemented based on the Regulation of the Minister of Education and Culture Number 12 of 2015 concerning Assistance for Poor Students (BSM). The Smart Indonesia Program (PIP) is given with the aim of reducing school dropout rates and encouraging dropouts to return to school. The high dropout rate and literacy rate are educational problems contained in the Strategic Plan (Renstra) of the Padang Lawas District Education Office in 2019. The dropout rate at the SMA/SMK level is still high, which is still higher than the target of the strategic plan, which is small from $1 \%$. Based on these data the authors are interested in researching "The Effectiveness of the Smart Indonesia Program in Sosa District"

\section{Methodology}

This study uses an evaluation research model, namely the Evaluation Countenance Stake model with a quantitative approach. The Stake Model emphasizes the implementation of two main things, namely: description and judgments. These two main points are obtained through an overview of the evaluation components which include, 1) input (antecendent), 2) process (transaction/process), and 3) product (outcomes). Based on the Countenance Stake model, there are three stages in the implementation of the program, namely; antecedents, transactions and outcomes. Assessing an educational program, it is necessary to do a relative comparison between one program and another, or an absolute comparison (one program with a standard). The emphasis generally is on evaluators making judgments about the program being evaluated. Based on the evaluation of the Stake model that considers the description and considerations, in this study the description which includes readiness, implementation process and utilization of funds is compared with considerations of readiness, implementation process and utilization of funds in accordance with technical guidelines issued by the Ministry of Education and Culture. The population in this study were all 153 students who received the Smart Indonesia Program for Senior High Schools in Sosa District, and the sample was taken using Isaac Michael's table totaling 105 people with an error rate of 5\%. Data obtained using questionnaires and interviews, then analyzed descriptively statistically

\section{Results and Discussion}

From the research results, it is known that respondents' responses to the implementation of the Smart Indonesia Program in Sosa District can be seen in table 2. 
Table 2. Frequency distribution of respondents' responses to the evaluation of the Smart Indonesia Program

\begin{tabular}{|c|c|c|c|c|c|}
\hline No. & Aspect & Category & Interval & $\mathrm{F}$ & $P$ \\
\hline \multirow[t]{5}{*}{1} & Antecedents & Very good & $16-20$ & 70 & $66,67 \%$ \\
\hline & (Masukan) & Good & $13-16$ & 24 & $22,86 \%$ \\
\hline & & Enough & $9-13$ & 4 & $3,81 \%$ \\
\hline & & $\mathrm{Bad}$ & $05-9$ & 1 & $0,95 \%$ \\
\hline & Rata-rata skor & & & \multicolumn{2}{|c|}{16,72 (Very Good) } \\
\hline \multirow[t]{5}{*}{2} & Transaction & Very good & $43-52$ & 15 & $14,29 \%$ \\
\hline & (Proses) & Good & $33-43$ & 33 & $31,43 \%$ \\
\hline & & Enough & $23-33$ & 53 & $50,48 \%$ \\
\hline & & $\mathrm{Bad}$ & $13-23$ & 4 & $3,81 \%$ \\
\hline & Rata-rata skor & & & \multicolumn{2}{|c|}{ 34,55 ( Good) } \\
\hline \multirow[t]{5}{*}{3} & Output & Very good & $39-48$ & 18 & $17,14 \%$ \\
\hline & (keluaran) & Good & $30-39$ & 55 & $52,38 \%$ \\
\hline & & Enough & $21-30$ & 30 & $28,57 \%$ \\
\hline & & $\mathrm{Bad}$ & $12-21$ & 2 & $1,90 \%$ \\
\hline & Average score & & & \multicolumn{2}{|c|}{33,06 (Good) } \\
\hline
\end{tabular}

Source: Data Analysis Results (2020)

From table 2. It is known that the average score of respondents' responses to the antecedents aspect (input) of 16.72 falls into the very good category, the average score of the transaction (process) aspect of 34.55 falls into the good category and the average score of aspects output (output) of 33.06 is included in the good category. Based on these results, it is known that the highest score of respondents' responses is in the antecedents aspect (input).

Table 3. Analysis of the Percentage of Respondents' Responses to the Evaluation of the Smart Indonesia Program

\begin{tabular}{lllll}
\hline No. & Aspect & Score & P & Category \\
\hline 1 & Antecedents (Masukan) & 1.756 & $83,62 \%$ & Very Good \\
2 & Transaction (Proses) & 3.628 & $66,45 \%$ & Good \\
3 & Output (keluaran) & 3.471 & $68,87 \%$ & Good \\
\hline
\end{tabular}

Source: Data Analysis Results (2020)

From table 3. it can be seen that the largest percentage of the results of the evaluation of the implementation of the Smart Indonesia Program is in the antecedents aspect (input) with a percentage of $83.62 \%$ and falls into the very good category, while in the transcation (process) and output (output) aspects, it is in the very good category. These results indicate that the implementation of the Smart Indonesia Program has been running well and in accordance with existing technical guidelines. 
Table 4. Percentage Analysis of Respondents' Responses to the Indicators for Evaluation of the Smart Indonesia Program

\begin{tabular}{|c|c|c|c|c|c|}
\hline No. & Aspect & Indicator & Score & $P$ & Category \\
\hline \multirow[t]{5}{*}{1} & \multirow{5}{*}{$\begin{array}{l}\text { Antecedents } \\
\text { (Masukan) }\end{array}$} & Program goal & 338 & $92,38 \%$ & Sangat Baik \\
\hline & & Program target & 224 & $53,33 \%$ & Cukup \\
\hline & & $\begin{array}{l}\text { PIP recipient student } \\
\text { requirements }\end{array}$ & 367 & $87,38 \%$ & Sangat Baik \\
\hline & & Amount of funds received & 387 & $92,14 \%$ & Sangat Baik \\
\hline & & Proposal Mechanism & 390 & $92,86 \%$ & Sangat Baik \\
\hline \multirow[t]{2}{*}{2} & \multirow{2}{*}{$\begin{array}{l}\text { Transaction } \\
\text { (Proses) }\end{array}$} & PIP Fund Distribution & 1478 & $58,65 \%$ & Cukup \\
\hline & & PIP Fund Disbursement Dana & 2150 & $73,13 \%$ & Baik \\
\hline \multirow[t]{2}{*}{3} & \multirow{2}{*}{$\begin{array}{l}\text { Output } \\
\text { (keluaran) }\end{array}$} & Utilization of funds & 1478 & $69,52 \%$ & Baik \\
\hline & & $\begin{array}{l}\begin{array}{l}\text { Obligations of PIP recipient } \\
\text { students }\end{array} \\
\end{array}$ & 2150 & $67,95 \%$ & Baik \\
\hline
\end{tabular}

Source: Data Analysis Results (2020)

From table 4, it can be seen that in the Antecedent aspect the lowest score is in the program target indicator with a percentage value of $53.33 \%$ in the sufficient category. This can be interpreted that based on the respondent's assessment the Smart Indonesia Program is considered quite right on target. The school has made efforts so that program recipients are students who really need and comply with predetermined criteria, but the low assessment of program target indicators indicates that there are indications that PIP recipients are still not right or in accordance with the intended target.

In the Transaction Aspect, it is known that the lowest score is in the fund distribution indicator with a percentage value of $58.65 \%$ and is in the sufficient category. This can be interpreted that based on the respondents' assessments, the distribution of the Smart Indonesia Program funds is considered adequate. The process of channeling funds involves other parties as distributors, namely through banks. Before the distribution of funds is carried out, students who have been declared as recipients of the Smart Indonesia Program are given socialization and information about the Smart Indonesia Program. Furthermore, students are asked to notify parents to be given socialization related to the program implementation process. In the aspect of output (output) The lowest score in the aspect of output (output), namely the indicator of the obligation of students receiving the Smart Indonesia Program of $67.95 \%$ falls into the good category. This indicates that students have carried out their obligations as recipients of assistance properly and in accordance with existing provisions. 
Table 5. Analysis of the Effectiveness of the Smart Indonesia Program

\begin{tabular}{|c|c|c|c|}
\hline Aspect & Indicator & Persentase & $\begin{array}{l}\text { Effectiveness } \\
\text { Level }\end{array}$ \\
\hline \multirow{6}{*}{$\begin{array}{l}\text { Antecedents } \\
\text { (Masukan) }\end{array}$} & Program Objectives & $92,38 \%$ & Very effective \\
\hline & Program target & $53,33 \%$ & Ineffective \\
\hline & $\begin{array}{l}\text { PIP recipient } \\
\text { requirements }\end{array}$ & $87,38 \%$ & Very effective \\
\hline & Amount of funds received & $92,14 \%$ & Very effective \\
\hline & Proposal mechanism & $92,86 \%$ & Very effective \\
\hline & $\begin{array}{l}\text { Effectiveness aspect of } \\
\text { Antecedents (Input) }\end{array}$ & $83,62 \%$ & Very effective \\
\hline \multirow[t]{3}{*}{ Transactio( Proses) } & PIP fund disbursement & $58,65 \%$ & Ineffective \\
\hline & PIP disbursement & $73,13 \%$ & Effective enough \\
\hline & $\begin{array}{l}\text { Transaction (Process) aspect } \\
\text { effectiveness }\end{array}$ & $66,45 \%$ & Effective enough \\
\hline \multirow[t]{3}{*}{ Output (Keluaran) } & Utilization of funds & $69,52 \%$ & Effective enough \\
\hline & $\begin{array}{l}\text { Obligations of PIP recipient } \\
\text { students }\end{array}$ & $67,95 \%$ & Effective enough \\
\hline & $\begin{array}{l}\text { Effectiveness aspect of Output } \\
\text { (Output) }\end{array}$ & $68,87 \%$ & Effective enough \\
\hline Rata-rata & $\begin{array}{l}\text { The Effectiveness of the Smart } \\
\text { Indonesia Program }\end{array}$ & $75,52 \%$ & Effective enough \\
\hline
\end{tabular}

Based on the results of the effectiveness analysis in table 5. it can be seen that there are two indicators that are not effective, namely program targets and the distribution of funds for the Smart Indonesia Program with a percentage of $53.33 \%$ and $58.65 \%$. Based on the results of the research found, in the implementation process there are still students who can be classified in the target group of aid program recipients who are not registered as beneficiaries. The Smart Indonesia Program is a program that targets children who come from the poor or from certain groups who receive consideration. certain (special) that have been regulated in the regulations. In fact, many have questioned the issue of the eligibility status of the beneficiaries. There are many complaints about the existence of children who should not deserve assistance, but get the Smart Indonesia Card. This problem often occurs due to data validity. The proposal submitted by the school through the dapodik for prospective beneficiaries is considered not to be realized. Often the names that appear as program recipients are names that were not proposed. Therefore, the school must be more careful in proposing potential beneficiaries to match the targets to be addressed.

The lowest value in the process aspect is in the indicator of disbursement of funds with a percentage of $58.65 \%$ in the ineffective category. The Smart Indonesia Program assistance funds are channeled through pre-determined channeling banks. Based on the research findings, it is shown that the distribution of aid funds using channeling banks is considered ineffective. This is caused by bureaucratic factors and services from channeling banks. In addition, the bank also has other customers who are more profitable and become a priority, so that the service to 
the recipients of the Smart Indonesia Program is less than satisfactory and maximal.

The implementation of the Smart Indonesia Program for High School and Vocational High School Students in Sosa District has been quite effective and is running as expected, starting from the stages of proposing, determining recipients, socialization to schools and parents of students, distributing funds, collecting funds to monitoring the implementation of the Smart Indonesia Program. However, there are still shortcomings, such as the inaccurate target of the Smart Indonesia Program recipients and the complicated distribution of funds for the Smart Indonesia Program because it must involve a third party in the distribution process. There is a need for continuous improvement and control so that the implementation of the Smart Indonesia Program can run well and achieve the expected maximum effectiveness.

\section{Conclusion}

From the evaluation process of the Smart Indonesia Program, it is known that the overall implementation of the Smart Indonesia Program in Sosa District is in the good category. Furthermore, it is seen from several aspects related to the implementation of the Smart Indonesia Program in Sosa District, namely the Antecedents aspect (input) is in the very good category, the transaction (process) category is in the good category and the output (output) category is in the good category. Thus, it can be stated that the implementation of the Smart Indonesia Program in Sosa sub-district has been carried out effectively, however, to be even more effective in implementing this program, it is hoped that the program implementers involved will be more selective in the process of submitting prospective recipients of the Smart Indonesia program, providing socialization to students and parents related to the distribution of the Indonesia Pinta Program, and formed a monitoring team on the use of funds for the Smart Indonesia Program.

\section{References}

Ananda, R., \& Rafida. T. 2017, Pengantar Evaluasi Program Pendidikan, Medan: Perdana Publishing

Astuti, R. S. (2017). Implementasi kebijakan kartu indonesia pintar dalam upaya pemerataan pendidikan tahun ajaran 2015/2016 di $\operatorname{smp}$ n 1 semin. Spektrum Analisis Kebijakan Pendidikan, 6(2), 121-127.

Aziz, A. R. (2019). Implementasi Instruksi Presiden (Inpres) No 07 Tahun 2014 tentang Kebijakan Kartu Indonesia Pintar (KIP) dalam Meningkatkan Mutu Pendidikan Masyarakat Miskin di Indonesia. Jurnal Pemerintahan dan Politik, 4(2).

Darodjat, D., \& Wahyudhiana, W. (2015). Model evaluasi program pendidikan. Islamadina: Jurnal Pemikiran Islam, 1-23. 
Harahap, Y., Makhdalena, M., \& Zulkarnain, Z. Pengaruh kualitas pelayanan akademik dan sarana prasarana pendidikan terhadap kepuasan mahasiswa fakultas keguruan dan ilmu pendidikan (fkip) universitas riau. Jurnal JUMPED (Jurnal Manajemen Pendidikan), 7(1), 116-128.

Kamsihayati, S., Sutomo, S., \& Suwarno, S. (2017). Kajian faktor-faktor penyebab anak putus sekolah di Desa Jangrana Kecamatan Kesugihan Kabupaten Cilacap. Geo Edukasi, 5(1).

Karmila, K. (2019). Efektivitas Program Indonesia Pintar (PIP) Terhadap Rintisan Wajib Belajar 12 Tahun Di Kecamatan Blangkejeren Kabupaten Gayo Lues. Jurnal Ilmiah Mahasiswa Fakultas Ilmu Sosial \& Ilmu Politik, 4(4).

Machali, I. (2018). The Handbook of Education Management: Teori dan Praktik Pengelolaan Sekolah/Madrasah di Indonesia Edisi 2 (Vol. 2). Prenada Media.

Mutiarin, D., 2014, Manajemen Birokrasi dan Kebijakan, Yogyakarta: Pustaka Pelajar.

Pagau, R. M., Kimbal, M., \& Kumayas, N. (2018). Efektivitas pembinaan warga binaan di lembaga pemasyarakatan klas iia manado. Jurnal eksekutif, 1(1).

Pasalong, H. 2013, Teori Administrasi Publik. Bandung: Alfabeta.

Rohaeni, N. E., \& Saryono, O. (2018). Implementasi Kebijakan Program Indonesia Pintar (PIP) Melalui Kartu Indonesia Pintar (KIP) dalam Upaya Pemerataan Pendidikan. Indonesian Journal of Education Management \& Administration Review, 2(1), 193-204.

Saraswati, L. N. (2017). Implementasi Kebijakan Program Indonesia Pintar (PIP) pada Jenjang Sekolah Dasar di Kecamatan Sungai Pinang Kota Samarinda. EJournal Administrasi Negara, 5(4), 6737-6750.

Sondang P. Siagian., 2008. Manajemen Sumber Daya Manusia. Bumi Aksara, Jakarta.

Suarman, S., Sumarno, S., \& Arum, A. (2011). Analisis Kepuasan Mahasiswa terhadap Kualitas Pembelajaran Dosen Program Studi Pendidikan Ekonomi Fkip Universitas Riau. Jurnal Pendidikan Ekonomi dan Bisnis, 3(03), 8981.

Suhardan, D 2012, Ekonomi dan Pembiayaan Pendidikan. Bandung; Jakarta.

Tamam, B. (2018). Reorientasi Pendanaan Pendidikan Dalam Membangun Mutu Sekolah. Misykat Al-Anwar, 29(2), 257189.

Togatorop, M. (2017). Pengaruh biaya pendidikan terhadap mutu sekolah SMA swasta. SCHOLARIA: jurnal Pendidikan dan Kebudayaan, 7(3), 234-240.

How to cite this article:

Liza, E., Suarman, \& Gusnardi. (2021). The Effectiveness of The Smart Indonesia Program (PIP) in Sosa District. Journal of Educational Sciences, 5(3), 533-541. 